\title{
Field Evaluation of Different Insecticides against Aphids (Homoptera: Aphidae) on Different Wheat, Triticum aestivum Varieties at Khairpur, Sindh
}

\author{
Hakim Ali Sahito $^{1^{*}}$, Bilawal ul Din Ghumro ${ }^{1}$, Tasneem Kousar ${ }^{1}$, Zafar Hussain Shah ${ }^{1}$, Tanveer \\ Ali Pittafi ${ }^{1}$, Sajid ur Rehman Bhutto, Faheem Ahmed Jatoi ${ }^{1}$, Wali Muhammad Mangrio ${ }^{1}$ \\ ${ }^{I}$ Department of Zoology, Faculty of Natural Sciences, Shah Abdul Latif University, \\ Khairpur Mir's, Sindh, Pakistan.
}

*Corresponding Author: Hakim Ali Sahito, Department of Zoology, Faculty of Natural Sciences, Shah Abdul Latif University, Khairpur Mir's, Sindh, Pakistan

\begin{abstract}
The Plumose and combination of two different (Bio-Cal 28\%, Crop Supplement and Crown 200 $S L)$ insecticides were evaluated on different wheat varieties cultivated under field conditions on randomized complete block design at district Khairpur, Sindh. Result further indicated that, during the research study only ten different varieties were selected namely; Abadgar-93, TJ-83, TD-1, Imdad, SKD-1, Yakhora, Pavan, Moomal, Mehran-89 and Anmol-91. The plumose insecticide reduced the overall mean percent population of green aphids on variety Moomal up to (49\%) followed by TJ-83 (42\%) and TD-1 (38\%) whereas; the least percent population was observed on Anmol (13\%). Thus, the mixture of two different Crown and Bio-Cal insecticides reduced the overall mean percent population of green aphids on variety Abadgar-93 up to (78\%) followed by Mehran-89 (71\%) and Imdad (39\%) with the least percent population was observed on Moomal (13\%), respectively. The correlation and regression analysis showed the direct impact of predators to the pest management and coefficient was negetively in constant values and positive to the independent values on different wheat varieties cultivated under field conditions of control plot. It is suggested that the population of wheat aphids should be regularly monitored and aphid's tolerant varieties should be grown for reducing losses. Besides, environmental friendly pesticides shall be applied against aphids on wheat.
\end{abstract}

Keywords: Green aphid, Pesticides, Plumose, Bio-Cal and Crown, Wheat crop.

\section{INTRODUCTION}

Wheat, Triticum aestivum (L) is the main staple food of the world population, feeding more than one billion people of the world. It is rich in protein and calories than any other cereal crop (Abd-ElHaleem et al., 2009). In Pakistan wheat contributes $14.4 \%$ to agriculture and $3.1 \%$ to GDP with production increased to 24.231 thousand tons in 2012-13 as compared to 23.471 thousand tons in previous years that showing an increase of 3.2\% (MINFA, 2013). It is a staple food in Pakistan that grown on 8414 million hectares producing 21749 million tons of grain with a yield of $2585 \mathrm{~kg}$ per hectare (MINFAL, 2008). The main cash crop cultivated with the largest area under cultivation in Pakistan (Anwar et al., 2009). The wheat crop is encountered by both biotic and abiotic stresses comprising of drought temperature, diseases and insect pests (Akhtar et al., 2010). Mostly, it is attached by sucking pest aphid which is known as a dangerous problem for wheat and cereal crops (Dixon, 1987). Aphid populations stay on wheat for a short period during which they multiply rapidly. Besides, there are so many insect pests that damage to this crop in this country; among of them the severe infestation is caused by aphids that loss directly and indirectly up to 35-40\% through sap sucking from plants and by transmitting 20-80\% viral and fungal diseases (Aslam et al., 2005). The reduction in crop yield reached up to 10-50 \% (Trdan and Milevoj, 1999). Thus, the population density also depends upon abiotic factors (Aheer et al., 2007 and 2008; Wains et al., 2008).

Aphids, Lipaphus erisymi, Kalt (Aphididae: Homoptera), often called plant lice and green flies have a wide host range, significantly affect various field crops, fruits and vegetables (Aheer et al., 2008). Population of aphids has been increasing from 1990s and has got status of pest in Pakistan (Zia et al., 1999). The first wheat aphid species; Diuraphis anoxia (Mordvilko) was reported by Grossheim 
Field Evaluation of Different Insecticides against Aphids (Homoptera: Aphidae) on Different Wheat, Triticum aestivum Varieties at Khairpur, Sindh

around 1900 in the Mediterranean Sea region and in southern Russia (Jones et al., 1989; Elsidaig and Zwer, 1993). It is assumed that aphid species spread from West Asia to the USA and Canada via South Africa and Mexico (Saidi and Quick, 1996). (Shah et al., 2006) reported the Bird cherry oat aphid, Rhopalosiphum padi, the English grain aphid, Sitobion avenae and the Green bug, Schizaphis graminum are the major wheat aphid species in North West Frontier province of Pakistan. Aphids are the most important pests particularly from the disease point of view. They possess piercing and sucking mouthparts, which are used to suck juices from various parts of plant and cause indirect damage by transmission of barley yellow dwarf virus (Carter et al., 1980; Gair et al., 1983; Mann et al., 1997). The most emerging problems causing serious threat to wheat crop in Pakistan when population level increases to outbreak level to direct yield losses (Inayatullah et al., 1993). The chemical control is one of the quick strategies, and takes a vital role in (IPM) strategy to decrease the sucking pests (Sahito et al., 2015). Therefore, present studies were conducted on different wheat affected varieties to investigate the control measures against this vigorous pest through pesticides under field conditions.

\section{Materials AND Methods}

The research study was carried out on green aphid, Schizophis graminum (Rondani) (Homoptera: Aphididae) population management through different insecticides on wheat cultivated crop under field conditions at district Khairpur, Sindh - Pakistan in Rabi season during, 2017. The data was taken early in the morning when temperature was below the $20^{\circ} \mathrm{C}$. The data were collected randomly per plant on weekly basis from each wheat verity. During the field study the population of nymphs and adults were found and count was made either male with winged form or female with no wings (wingless). Further, the data was taken from the spike of the plant therefore the ten spikes were selected from each and every treatment. Therefore, there were the ten treatments which were replicated three times. The area of five acres were divided in ten plots and each plot had three sub plots to show its replications having same size and seed was cultivated through broad casting method for each variety. Besides, only $1 / 3$ piece of one another acre piece of agriculture land was reserved for the control plot to check its pest population and its natural enemies in which no any pesticide was used. The research was conducted on randomized complete block design (RCBD) having 2 treatments of pesticides and replicated 3 times.

\section{Spraying scheduled:}

When first appearance of pest, green wheat aphid was observed, the data was taken before the use of pesticides and after as pre-treatment and post-treatment observations. Thus, the application of pesticides, the effect of its application was checked out, having taken data after $2^{\text {nd }}, 3^{\text {rd }}$ and $5^{\text {th }}$ day as 24, 48, 72 hours and $5^{\text {th }}$ day, respectively. When population reached at Economic Threshold Level (ETL) of 30-35 aphids per $10 \mathrm{~cm}$ inflorescence or spike of wheat plant, the spray was scheduled to reduce the aphid pest population. The spray was done through shoulder knapsack spray pump / tank bearing hollow cone nozzle in which the pesticides were mixed with tap water. The sprayer tank possessed with 18 litter of water (made in China) in steal body which was charged with electricity (having charging battery) at night and in day was used for spraying the crop. The nozzle distance from plant was about $60 \mathrm{~cm}$. The spraying was done at morning time, during the spray for safety measures were also applied; the hand gloves, socks with boot, googles, head covered with cloth like turban and mouth mask were used as well.

\section{Different wheat varieties:}

The wheat varieties $(n=10)$ were started to cultivate in the first week of November as plots and sub plots were made and different varieties were cultivated up to last week of the same month. All the varieties were cultivated on same day with the help of three labors who were paid with daily payable labor, DPL. The registered and cultivar wheat varieties namely; $1=$ TJ-83 (1985), $2=$ Mehran-89 (1991), $3=$ Anmol-91 (1993), 4= Abadgar-93 (1996), 5= Moomal-2002 (2002), 6= TD-1 (2004), $7=$ SKD-1 (2006), $8=$ Imdad (2006), 9= Yakhora and 10 Pavan were kept for pest management purpose through different insecticides. Whereas; in control plot, the all ten varieties seed was mixed as one kilogram of each variety spread as broad casting method to check the population fluctuation of pest with its naturally occurrence of predators. These different varieties were also found to be matured 
Field Evaluation of Different Insecticides against Aphids (Homoptera: Aphidae) on Different Wheat, Triticum aestivum Varieties at Khairpur, Sindh

within 115-150 days having 40 to 65 yield's potential in mounds per acre whereas; the average yield was observed 30-60 mounds per acre as well.

\section{Pesticides application with different doses:}

The pesticides were purchased from registered dealer shop located at city Khairpur. There were different pesticides such as; $1_{=}$Plumose and $2=$ combination of two different pesticides (Bio-Cal 28\%, Crop Supplement and Crown ${ }^{\mathrm{TM}} 200 \mathrm{SL}$ ) applied in different wheat cultivated crop. For this purpose; there were two treatments of pesticides were kept and replicated three times at tenth day of same month on different wheat varieties when pest appeared and in control plot, in which the insecticide was forbidden to check the naturally population fluctuation management. The different doses of each insecticide; Plumose $=800 \mathrm{ml}$ per acre and $100 \mathrm{ml}$ per tank and combination of two different insecticides 50 and $50=100 \mathrm{ml}$ per tank were applied. The insecticides solution was prepared on the basis according to their label recommended doses. The pest scouting was carried out before the use of these insecticides and data was taken when this pest was observed at its economic threshold level. The pre and post-treatment was evaluated with overall mean population whereas; the mortality percent population evaluated through under given formula:

$$
\text { Percentage }(\%)=\frac{\text { Post }- \text { treatment data }}{\text { Pre }- \text { treatment data }} \times 100
$$

\section{Statistical analysis:}

Finally, the data was inserted in MS, excel spread sheet and latter on imported for analysis of variance for examination the significant results with the help of SXW software, 8.1, version (USA).

\section{RESUlts}

\section{Evaluation of plumose insecticide against wheat aphids:}

The wheat crop cultivated under field conditions was observed with green aphids, Schizaphis gramium (Rondani) population. When plant bearded the spikes at puberty age, the green aphid population was observed after 2 months cultivation of the crop, the pre-treatment and after application of insecticides the post-treatment data was also taken during the winter / rabi season in the months of January to March, 2017. Results further indicated that pretreatment of pest population was observed on Anmol-91 with infestation (16.74) followed by Yakhora (14.52), Pavan (13.56), Mehran-89 (13.14), Imdad (12.64), SKD-1 (8.78), TD-1 (7.98), Moomal (4.35), TJ-83 (3.42) and Abadgar-93 was (1.56). After 24 hours of spray heavily infestation was observed on variety TD-1 (5.46) followed by Mehran-89 (3.67), Pavan (2.26), Moomal (1.92), TJ-83 (1.56), Imdad (1.52), Yakhora (1.20), Anmol-91 (1.14), SKD-1 (0.64), Abadgar-93 (0.24). After 24 hrs maximum overall mean pest population was observed on TD-1 (5.46) while minimum on Abadgar-93 (0.24), respectively. After 48 hrs of spray heavily infestication was observed on Moomal (2.88) followed by TD-1 (2.80), Mehran89 (2.58), Yakhora (1.84), Imdad (1.12), SKD-1 (0.92), Anmol- 91 (0.86), Pavan (0.62), Abadgar-93 (0.28), TJ- 83 (0.10). After $48 \mathrm{hrs}$ the overall mean population was observed on Moomal- 2002 (2.88) while minimum on variety TJ-83 (0.10). After $72 \mathrm{hrs}$ of spray the infestation was observed on Mehran-89 (4.45) followed by Yakhora (3.82), Moomal (2.90), TD-1 (2.48), TJ- 83 (1.92), SKD-1 (1.54), Anmol- 91 (1.34), Imdad (0.98), Pavan (0.92), Abadgar-93 (0.60). After 72 hrs the overall mean pest population was observed on Mehran-89 while minimum on Abadgar-93 (0.60). On day $5^{\text {th }}$ of spray the sever infestation was observed on Mehran-89 (6.14), Yakhora (5.02), Imdad (3.90), Anmol-91 (2.46), TJ- 83 (2.10), TD-1 (1.51), Pavan (1.30), Abadgar-93 (1.14), SKD-1 (1.10), Moomal- 2002 (0.84). After day 5th the maximum pest population was observed on Yakhora (5.02) while minimum on Moomal- 2002 (0.84), respectively. Whereas; in the pre-treatment, the overall mean population of green aphid was observed on all wheat varieties was $(9.67 \pm 1.65)$ and the post-

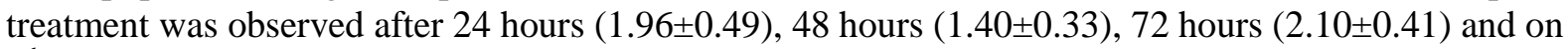
$5^{\text {th }}$ day $(2.55 \pm 0.58)$, respectively (Table- 5 ).

The analysis of variance showed the significant difference among all pesticides $(\mathrm{DF}=9,39 ; \mathrm{F}=3.75$; $\mathrm{P}=0.003)$ used to control the green aphids population at $(\mathrm{P}<0.05)$. The plumose insecticide reduced the overall mean percent population of green aphids on variety Moomal up to (49\%) followed by TJ- 
Field Evaluation of Different Insecticides against Aphids (Homoptera: Aphidae) on Different Wheat, Triticum aestivum Varieties at Khairpur, Sindh

$83(42 \%)$ and TD-1 (38\%) whereas the least \% population was observed on Anmol (13\%), respectively (Fig. 1).

Table. 1. Plumose insecticide used against wheat aphid population under field conditions

\begin{tabular}{|c|c|r|r|r|r|r|}
\hline \multirow{2}{*}{\multicolumn{2}{|c|}{}} & \multirow{2}{*}{ Varieties } & \multicolumn{4}{|c|}{ Post-treatment } \\
\cline { 4 - 7 } 1 & Pre-treatment & 24 hrs. & 48 hrs. & 72 hrs. & 5 days \\
\hline 2 & Abadgar-93 & 1.56 & 0.24 & 0.28 & 0.60 & 1.14 \\
\hline 3 & TJ-83 & 3.42 & 1.56 & 0.10 & 1.92 & 2.10 \\
\hline 4 & TD-1 & 7.98 & 5.46 & 2.80 & 2.48 & 1.51 \\
\hline 5 & Imdad & 12.64 & 1.52 & 1.12 & 0.98 & 3.90 \\
\hline 6 & SKD-1 & 8.78 & 0.64 & 0.92 & 1.54 & 1.10 \\
\hline 7 & Yakhora & 14.52 & 1.20 & 1.84 & 3.82 & 5.02 \\
\hline 8 & Pavan & 13.56 & 2.26 & 0.62 & 0.92 & 1.30 \\
\hline 9 & Meomal (2002) & 4.35 & 1.92 & 2.88 & 2.90 & 0.84 \\
\hline 10 & Anmol-91 & 13.14 & 3.67 & 2.58 & 4.45 & 6.14 \\
\hline & Mean & $9.67 \pm 1.65$ & $1.96 \pm 0.49^{\text {ab }}$ & $1.40 \pm 0.33^{\mathrm{b}}$ & $2.10 \pm 0.41^{\text {ab }}$ & $2.55 \pm 0.58^{\mathrm{a}}$ \\
\hline
\end{tabular}

Each value is a mean of 3 replications, means in column followed by same letters are significantly different at $\mathrm{P}<0.05$.

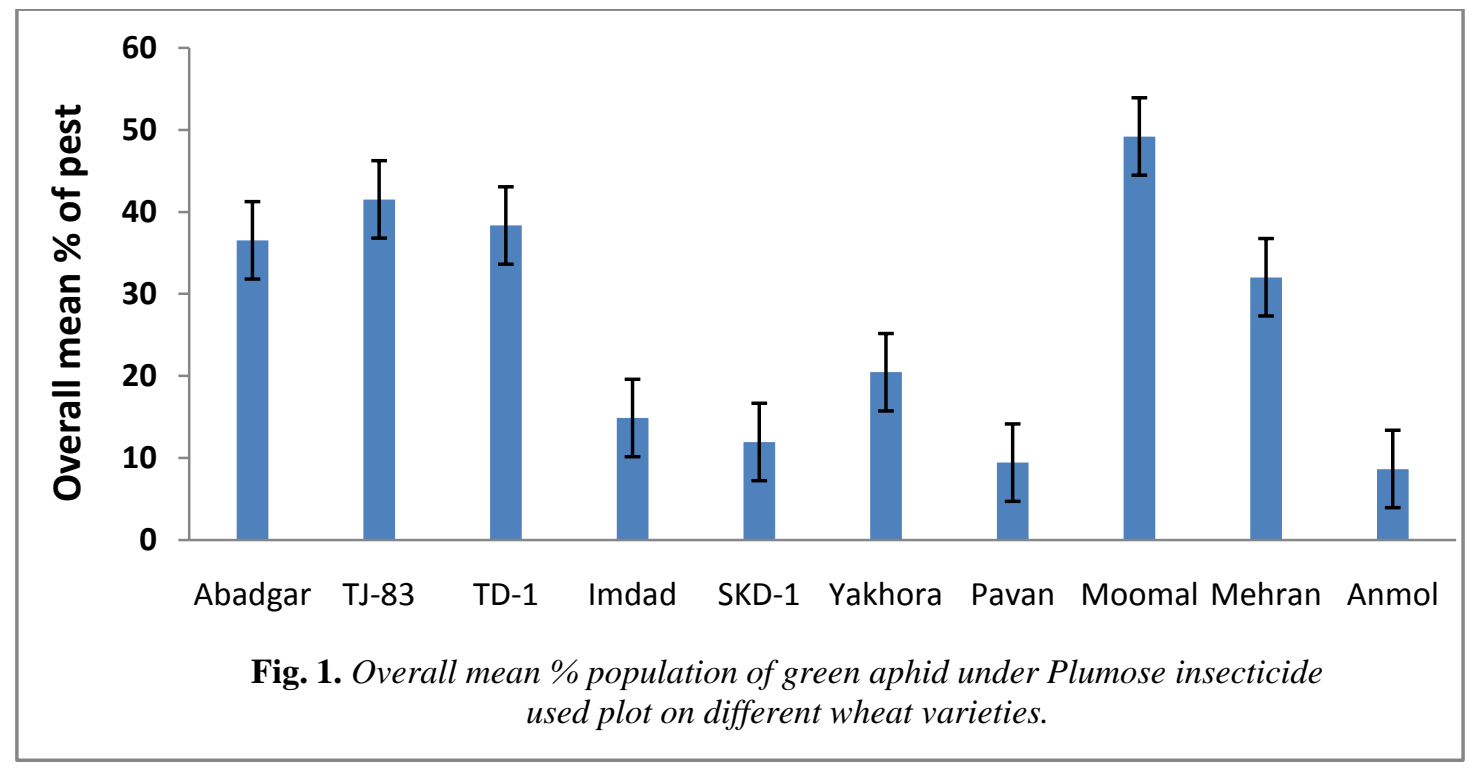

\section{Evaluation of Crown and Bio-Cal insecticides against wheat aphid:}

By using mixture of Crown and Bio-Cal insecticides, the results further indicated that pretreatment of pest population was observed on Moomal, (19.92) followed by TD-1 (14.46), Anmol-91 (12.92), Pavan (12.26), Yakhora (12.20), TJ-83 (11.56), Imdad (10.50), SKD-1 (8.70), Mehran-89 (4.67) and Abadgar-93 (2.24). After 24 hours of spray, the sever infestation was observed on variety Anmol-91 (4.46) followed by Yakhora (3.82), Moomal (3.58), Imdad (3.30), TJ-83 (2.80), Mehran-89 (2.08), TD-1 (1.90), Abadgar-93 (1.78), Pavan (1.14) and SKD-1 (0.90). After 24 hrs of spray, the maximum pest population was observed on variety Anmol- 91 (4.46) while; minimum on variety SKD-1 (0.90). After $48 \mathrm{hrs}$ of spray, the pest population was observed on variety Mehran- 89 (3.70) followed by variety Imdad (3.48), Yakhora (2.94), SKD-1 (2.66), Pavan (2.22), TD-1 (2.02), Abadgar-93 (1.50), Moomal- 2002 (1.26), TJ- 83 (1.10), Anmol- 91 (0.80). After $48 \mathrm{hrs}$ of spray; the maximum pest population was observed on variety Mehran- 89 while minimum on Anmol- 91. After $72 \mathrm{hrs}$ of spray; the sever infestation was observed on variety Imdad (4.48) followed by variety Mehran-89 (3.54), TD-1 (3.38), Pavan (3.10), TJ- 83 (3.04), Anmol- 91 (2.48), Moomal- 2002 (2.34), Yakhora (2.22), Abadgar-93 (2.14), SKD-1 (1.86). After $72 \mathrm{hrs}$ of spray, the maximum pest population was observed on variety Imdad while minimum on SKD-1, respectively. 
Field Evaluation of Different Insecticides against Aphids (Homoptera: Aphidae) on Different Wheat, Triticum aestivum Varieties at Khairpur, Sindh

On day $5^{\text {th }}$ after spray the heavily infestation was observed on variety Yakhora (5.82), followed by variety Imdad (4.98), Anmol- 91 (4.46), Mehran- 89 (4.00), Pavan (2.92), Moomal- 2002 (2.90), TD1 (2.48), TJ-83 (1.92), Abadgar-93 (1.60), SKD-1 (1.54). After $5^{\text {th }}$ day the maximum pest population was observed on Yakhora, while minimum on SKD-1, respectively (Table -2). The analysis of variance showed the significant difference among all varieties $(\mathrm{DF}=9,30 ; \mathrm{F}=2.38 ; \mathrm{P}=0.001)$ in wheat varieties at $(\mathrm{P}<0.05)$. Whereas; the pre-treatment overall mean population of green aphid was observed on all wheat varieties $(10.94 \pm 1.57)$ and the post-treatment was observed on 24 hours (2.58 \pm 0.38$)$, and 48 hours $(2.17 \pm 0.32)$ with the 72 hours $(2.86 \pm 0.25)$, and on $5^{\text {th }}$ day $(3.26 \pm 0.47)$, respectively (Table -2 ).

The mixture of two different Crown and Bio-cal insecticides reduced the overall mean percent population of green aphids on variety Abadgar-93 up to (78\%) followed by Mehran-89 (71\%) and Imdad (39\%) with the least \% population was observed on Moomal (13\%), respectively (Fig. 2).

Table 2. Mixture of Crown and Bio-cal insecticides used against wheat aphid under field condition

\begin{tabular}{|c|c|c|c|c|c|c|}
\hline & \multirow[b]{2}{*}{ Varieties } & \multirow[b]{2}{*}{ Pre-treatment } & \multicolumn{4}{|c|}{ Post-treatment } \\
\hline & & & $24 \mathrm{hrs}$ & $48 \mathrm{hrs}$ & $72 \mathrm{hrs}$ & $5^{\text {th }}$ day \\
\hline 1 & Abadgar-93 & 2.24 & 1.78 & 1.50 & 2.14 & 1.60 \\
\hline 2 & TJ-83 & 11.56 & 2.80 & 1.10 & 3.04 & 1.92 \\
\hline 3 & TD-1 & 14.46 & 1.90 & 2.02 & 3.38 & 2.48 \\
\hline 4 & Imdad & 10.50 & 3.30 & 3.48 & 4.48 & 4.98 \\
\hline 5 & SKD-1 & 8.70 & 0.90 & 2.66 & 1.86 & 1.54 \\
\hline 6 & Yakhora & 12.20 & 3.82 & 2.94 & 2.22 & 5.82 \\
\hline 7 & Pavan & 12.26 & 1.14 & 2.22 & 3.10 & 2.92 \\
\hline 8 & Moomal & 19.92 & 3.58 & 1.26 & 2.34 & 2.90 \\
\hline 9 & Mehran-89 & 4.67 & 2.08 & 3.70 & 3.54 & 4.00 \\
\hline 10 & Anmol-91 & 12.92 & 4.46 & 0.80 & 2.48 & 4.46 \\
\hline & Mean & $10.94 \pm 1.57$ & $2.58 \pm 0.38^{\mathrm{ab}}$ & $2.17 \pm 0.32^{\mathrm{b}}$ & $2.86 \pm 0.25^{a b}$ & $3.26 \pm 0.47^{\mathrm{a}}$ \\
\hline
\end{tabular}

Each value is a mean of 3 replications, means in column followed by same letters are significantly different at $\mathrm{P}<0.05$.

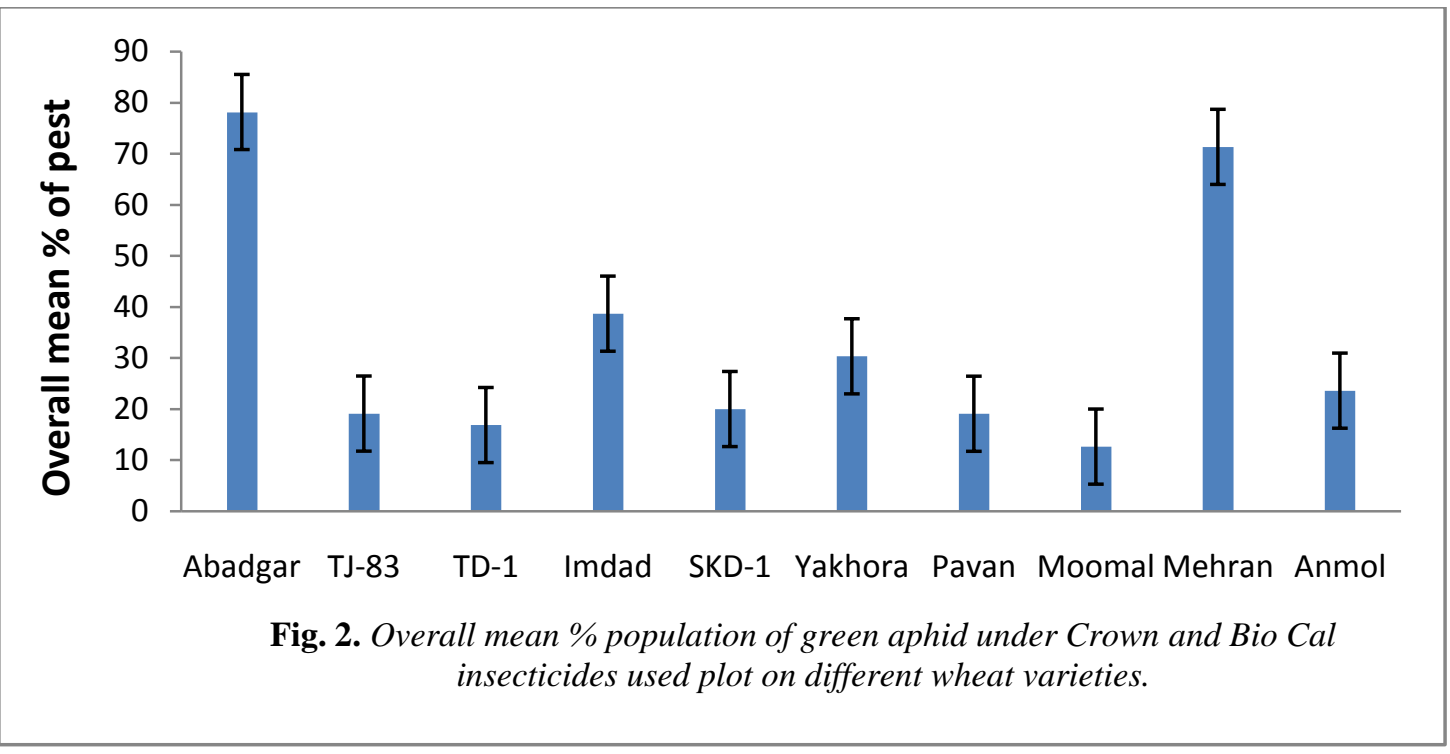

No any registered or cultivar wheat varieties which were kept under observation were found to be resistant / tolerant against wheat green aphid in three kept treatments, respectively. The overall mean population was observed on fortnightly interval basis in control plot with pest and predators population fluctuations. The most effected variety was observed Anmol-91 (27.92) followed by TJ-83 (6.62), SKD-1 (5.68), Pavan (15.26), TD-1 (14.46), Mehran-89 (12.67), Abadgar-93 (11.32), Imdad (7.55), Yakhora (6.20), Moomal (5.42), respectively. Whereas; the predators population was observed on variety TJ-83 (6.62) followed by SKD-1 (5.68), Anmol-91 (5.46), Pavan (4.28), Abadgar-93 
Field Evaluation of Different Insecticides against Aphids (Homoptera: Aphidae) on Different Wheat, Triticum aestivum Varieties at Khairpur, Sindh

(4.11), Yakhora (2.72), Moomal (1.40), TD-1 (1.06), Mehran-89 (0.88) and Imdad (0.18) with the overall mean of pest population on all varieties $(14.72 \pm 2.46)$ and predators $(3.24 \pm 0.73)$ were also observed. Most of them the lady bird beetles were observed such as; 7 spotted lady bird beetles, schymnus spp., spiders and green lace wing, respectively (Fig. 3).

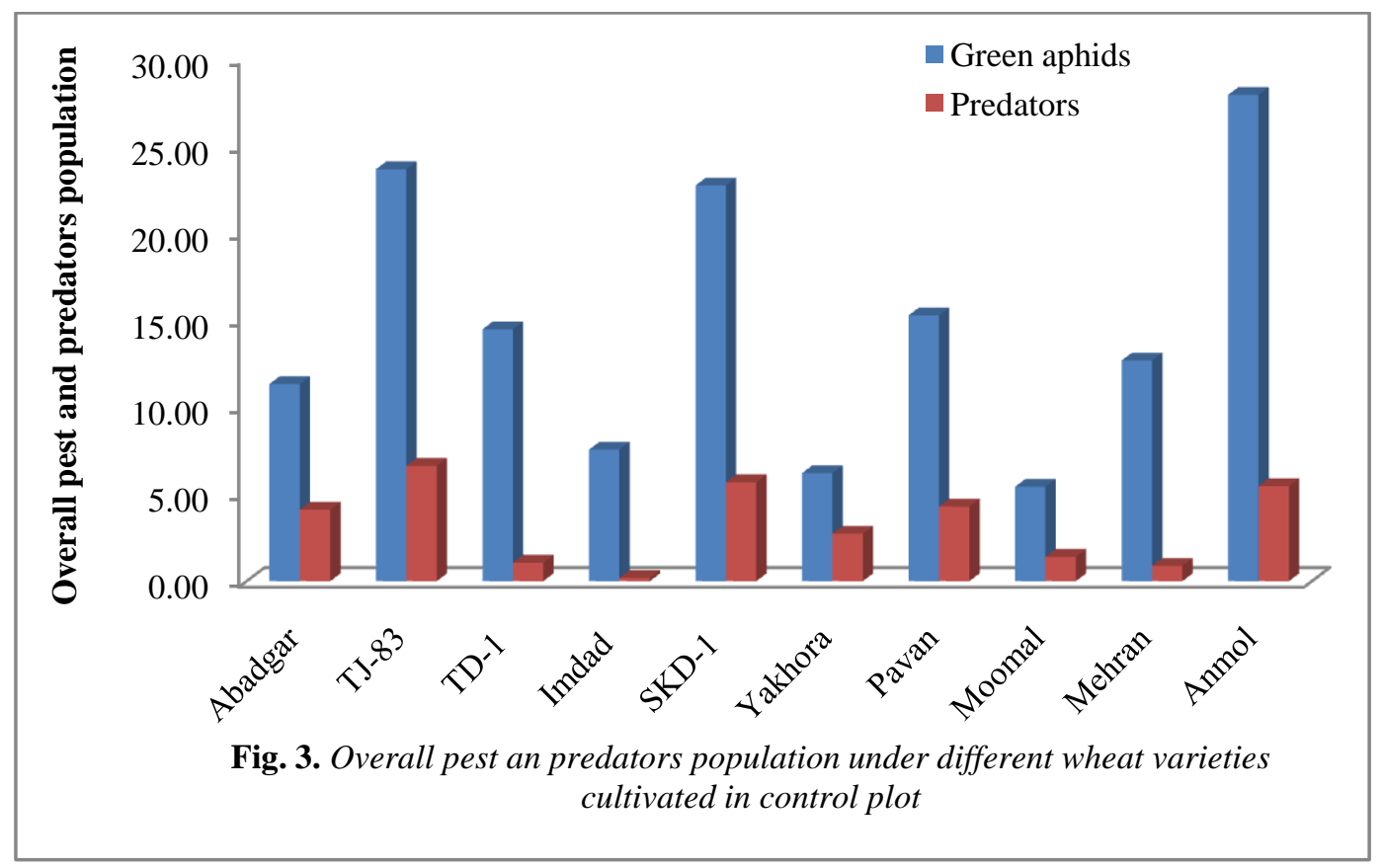

The analysis of varience showed the significant difference among all cultivated varieties $(\mathrm{DF}=1,8 ; \mathrm{F}=$ 12.46; $\mathrm{P}<0.005)$. The correlation and regression analysis showed the $(\mathrm{x}=0.7804 ; \mathrm{y}=0.005 ; \mathrm{P}<0.005)$ direct impact of predators to the pest management and Coefficient was negetively in constant values and positive to the independent values with standard errors $(-0.15243 ; \mathrm{SD}=1.07474$ and 0.23044 ; $\mathrm{SD}=0.06528)$ on different wheat varieties cultivated under field conditions of control plot, respectively (Fig. 4).

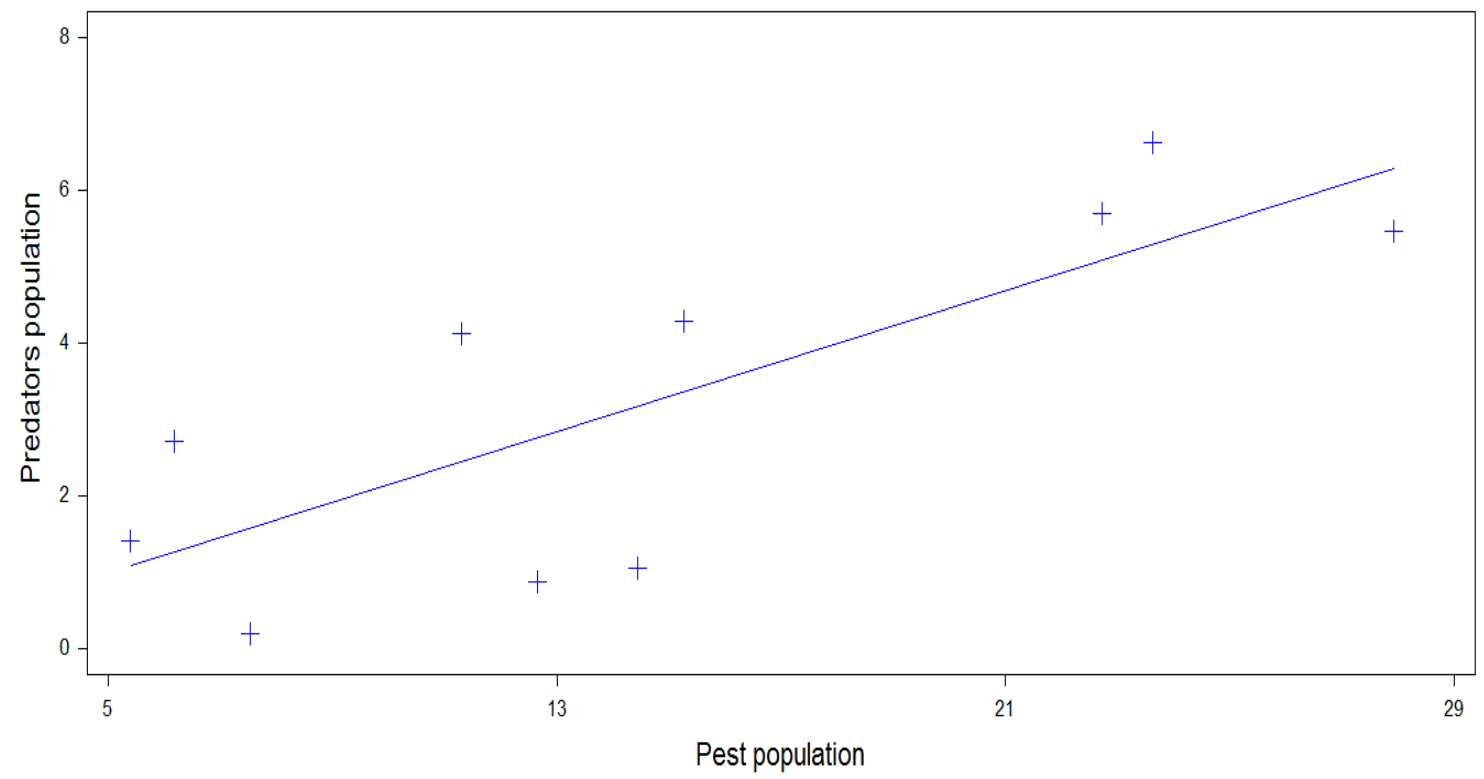

\section{DISCUSSION}

Fig. 4. Regression analysis $b / w$ pest and predators on wheat varieties

The capability of pesticides have been assessed against aphid on wheat cultivated with different registered and cultivar varieties under field conditions which were cultivated at farmers field district, Khairpur - Sindh. The wheat green aphid specie was found attacking on these varieties when plant bear spikes up to the full maturity of the crop when crop changed its colour from green to the golden. 
Field Evaluation of Different Insecticides against Aphids (Homoptera: Aphidae) on Different Wheat, Triticum aestivum Varieties at Khairpur, Sindh

Therefore, it was necessary to reduce pest population through different insecticides with prescribed doses at per interval basis under field conditions otherwise the whole crop would be damaged drastically. The aphid development found to be by differences in population growth as it increased in cloudy and rainy season when temperature became high the aphid population decreased under field conditions. It was also observed that when wheat crop started to be ripening the aphid population decreased. By using the chemical methods to control aphid population, certain pesticides were applied to control aphid pest population. Like; (Sahito et al., 2009 and 2011) evaluated the different cotton varieties cultivated under field conditions for population fluctuation and its management through different insecticides of sucking pest. The number change of pest was observed naturally under control plot; in which no any pesticide was used only water washed with the shoulder mounted backpack sprayer. The aphids number for the management from the naturally occurred beneficial insects as; predators, most of them only the voracious feeder, lady bird beetles were found under the control plot. The same like results were also found from (Karimullah and Ahmad, 1989) who observed aphids damage started in the first week of February and reached in the peak population in the middle of March to April. Besides, another research conducted by (Xiong, 1990) reported about the population of pest as aphids in the field increased with the development of the wheat and peaked at the heading stage. Whereas; (Yang, 1990) described the effects of temperature and light on the population growth of $S$. graminum that some time favors to increase the pest population.

Further, the different researchers showing the same results as Jansen, (2000) assessed short-term effects of six insecticides those were used to control aphids in wheat crop. We received the peak population of aphids on $2^{\text {nd }}$ week of March, Aheer et al., (2006) and Muhammad et al., (2005) reported the peak aphid population on $23^{\text {rd }}$ March (third weak March), Similarly; Aslam et al., (2004) observed the peak aphids population on $16^{\text {th }}$ March (third weak March). Farooq and Nasir, (2001) reported peak aphid population during the mid March and Shuhail et al., (2001) reported peak aphid population on $2^{\text {nd }}$ April as well. We found out that the aphids population became zero on $6^{\text {th }}$ April as (Aslam et al., 2004) recorded that aphids on all the tested wheat varieties was totally eliminated on $6^{\text {th }}$ April. But, Shuhail et al., (2001) reported that wheat aphid population became zero on $17^{\text {th }}$ April. This was observed difference in the date of peak level and zero population may be due to the difference in the weather factors of different locations. Aheer et al., (2007) also confirmed that combination of all abiotic factors (Temperature, Humidity and Rainfall) contributed a significant role in aphid population fluctuation on wheat. The aphids found to be most vulnerable insect pest in different wheat varieties cultivated under field conditions to suck the sap from juicy parts of the wheat plant. The results further indicated that the plumose was found more effective followed by combination of two different pesticides mostly used at this region, may be prescribed by the pesticides dealer, agriculture farmer own choice or land lord instructions such as; Crown and Bio-cal when compared with control plot. One way analysis of variance showed the significant difference among all tested pesticides at $(\mathrm{P}<0.05)$. Similarly, Kostyukovskii and Kushneuk, (1990) reported that the number of aphids increased at $15-18^{\circ} \mathrm{C}$ during earring and flowering of wheat crop which was recorded with sever infestation during grain development and initiation of wax ripening. The decline in the aphid population could also be the results of the crop maturity as stated by (Riedell, (1990) that damage of aphids on wheat crop was huge at the heading and flowering stages and was reduced during the maturity stage of the wheat crop. It is concluded that aphid can be controlled by using pesticides, the population of wheat green aphids that should be regularly monitored on different verities / lines. Aphid tolerant / resistant or cultivars varieties should be grown for reducing losses. Environmental friendly pesticides shall be applied against aphids on wheat pest most likely attack on wheat during January to mid of the April.

\section{RECOMMENDATIONS}

The population of wheat aphids should be regularly monitored on different verities/lines. Aphid's tolerant/resistant cultivars/varieties should be grown for reducing losses. Pesticides of Target Company shows good results so it should be used to control aphid population. Pesticides most be used in cloudy weather because cloudy weather is a favorable condition for pest appearance. Pest inhabiting varieties could also be cultivated. Early cultivation of wheat should be avoided because pest most likely attacks on early cultivated varieties. When spikes come out on wheat they should be closely observed on daily basis because spikes are most attractive part and food source for pest. 
Field Evaluation of Different Insecticides against Aphids (Homoptera: Aphidae) on Different Wheat, Triticum aestivum Varieties at Khairpur, Sindh

\section{ACKNOWLEDGEMENTS}

The authors are highly admired for the growers of district Khairpur for providing such a facility of cropping land to conduct the research study and Department of Zoology for spacing such a facility of Entomology laboratory at SALU, Khairpur.

\section{REFERENCES}

[1] Abd-el-Haleem, S.H.M., M.A. Reham and S.M.S. Mohamed. (2009). Genetic analysis and RAPD Polymorphism in some Durum wheat Genotypes. Global. Biotech. and Biochem., 4(1): 1-9.

[2] Aheer, G.M., A. Ali, M. Munir. (2008). Abiotic factors effect on population fluctuation of alate aphids in wheat. J. Agric. Res., 46 (4): 367-371.

[3] Aheer, G.M., M. Munir and A. Ali. (2006). Screening of wheat cultivars against aphids in ecological conditions of district Mandi Bahauddin. J. Agric. Res., 44(1): 55-58.

[4] Aheer, G.M., M. Munir and A. Ali. (2007). Impact of weather factors on population of wheat aphids at Mandi Bahaud- Din district. J. Agric. Res., 45(1): 61-66.

[5] Akhtar, L.H., M. Hussain, R.M. Iqbal, M. Amer and A.H. Tariq. (2010). Losses in grain yield caused by Russian wheat aphid Diuraphis noxia (Mordvilko) Sarhad J. Agric., 26(4): 625-629.

[6] Anwar, J., M.A. Ali, M. Hussain, W. Sabir, M.A. Khan, M. Zulkiffal and M. Abdullah. (2009). Assessment of yield criteria in bread wheat through correlation and path analysis. J. Anim. Plant Sci., 19(4): 185-188.

[7] Aslam, M., M. Razaq, W. Akhter, M. Faheem and F. Ahmad. (2005). Effect of sowing date of wheat on aphid (Schizaphis gramium Rondani) population. Pak Entomol., 27: 79-82.

[8] Aslam, M., M. Razaq, F. Ahmad, M. Faheem and W. Akhter. (2004). Population of aphids (Schizaphis graminum) on different varieties/lines of wheat (Triticum estivium L). Int'l. J. Agric. and Biol., 6(6): 947977.

[9] Carter, N., L.F.G. Mclean, A.D. Watt and A.F.G. Dixon. (1980). Cereal aphids, a case study and review. In: Applied Biology (ed. T.H. Coakr), 5: 271-348. Academic Press, London.

[10] Dixon, A.F.G. (1987). Cereal aphids as an applied problem. Agric. Zool. Rev., 2: 1-5.

[11] Elsidaig, A.A., and P.K. Zwer. (1993). Genes for resistance to Russian wheat aphid in PI 294994. Crop Sci., 33(5): 998-1001.

[12] Farooq, M., and S. Nasir. (2001). Varietal resistance of wheat germplasm against wheat aphids (Sitobion avenae). Ibid. 23(1-2): 5-7.

[13] Gair, R., J.E.E. Jenkins and E. Leater. (1983). Cereal pests and diseases. Farming Press Ltd., Norwitch.

[14] Inayatullah, C., M. Nahid, E. Haq, and M.F. Chaudary. (1993). Incidence of green bug, Schizophis graminum (Rondani) (Homoptera: Aphididae) in Pakistan and resistance in wheat against it. Insect Sci. and Appl., 14(2): 247-254.

[15] Jansen, J.P. (2000). A three-year field study on the short-term effects of insecticides used to control cereal aphids on plant-dwelling aphid predators in winter wheat. Pest Manag. Sci., 56(6): 533-539.

[16] Jones, J.W., J.R. Byers, R.A. Butts and J.L. Harris. (1989). A new pest in Canada: Russian wheat aphid, Diuraphis noxia (Mordvilko) (Homoptera: Aphididae). Can. Entomol., 82: 1779-1781.

[17] Karimullah, and K.F. Ahmad. (1989). Incidence of the cereal aphid Sitobion avenae (F) on different cultivars of wheat. Sarhad J. Agri., 5: 59-61.

[18] Kostyukovskii, M.G., and V.M. Kushnerik. (1990). Population dynamics of cereal leaf aphids on winter wheat. Zashchita Rastenii (Kiev). 37: 10-13.

[19] Mann, J.A., R. Harrington, N. Carter and R.T. Plumb. (1997). Control of aphids and barley yellow dwarf virus in spring sown cereals. Crop Protect., 16: 18-87.

[20] MINFAL. (2008). Statist. Govt. of Pakistan, Ministry of Food, Agric. and Livest. Econ. Wing, Islamabad. Pp. 273.

[21] MINFA., (2013). Economic Survey. Ministry of Food, Agriculture and Livestock, Government of Pakistan, Islamabad. Pp. 1.

[22] Muhammad, A., M. Razaq, W. Akhter, M. Faheem and F. Ahmad. (2005). Effect of sowing date of wheat on aphid (Schizaphis graminum Rondani) population. Pak. J. Entomol., 27(1): 79-82.

[23] Riedell, W.E. (1990). Tolerance of wheat to Russian wheat aphids: Nitrogen fertilization reduces yield loss. J. Plant Nutri., 13: 579-584.

[24] Sahito, H.A., G.H. Abro, R.D. Khuhro and A.S. Buriro. (2009). Varietal resistance of cotton crop against mealybug, Phenacoccus solenopsis (Tinsley). Pak. J. Agri., Agri. Engi. and Vet. Sci., 25: 34-38. 
Field Evaluation of Different Insecticides against Aphids (Homoptera: Aphidae) on Different Wheat, Triticum aestivum Varieties at Khairpur, Sindh

[25] Sahito, H.A., G.H. Abro, T.S. Syed, S.A. Memon, B. Mal and S. Kaleri. (2011). Screening of pesticides against cotton mealybug, Phenacoccus solenopsis (Tinsley) and its natural enemies on cotton crop. Inter. Res. J. Bioch. and Bioinf., 1: 232-236.

[26] Sahito, H.A., Z.H. Shah, M. Ruk, M. Z. Shah and W.M. Mangrio. (2015). Toxicant efficacy of some insecticides against whitefly, Bemesia tabaci under cotton field conditions at Khairpur-Sindh. Academic J. Ento., 8: 193-200.

[27] Saidi, A., and J.S. Quick. (1996). Inheritance and allelic relationships among RAW resistance genes in winter wheat. Crop Sci., 36(2): 256-258.

[28] Shah, A.K., F. Ullah, N. Hussain. A.U.R. Saljoqi, Y. Hayat and S. Sattar. (2006). Distribution pattern of the cereal aphids in the wheat growing areas of the province Khyber Pukhtunkhwa of Pakistan. Sarhad J. Agric., 22(14) 7: 291-294.

[29] Shuhail, A.R., N. Bibi, Perveen and M. Ahmad. (2001). Population dynamic of aphids (Macrosiphum mescanthitak) on different wheat varieties. Pak. J. Biol. Sci., 4(2): 131-132.

[30] Trdan, S., and L. Milevoj. (1999). The cereal aphid (Sitobion avenae F.) wheat pest. Sodobno-Kmetijstvo, 32(3): 119-128.

[31] Wains, M.S., A. Rehman, M. Latif and M. Hussain. (2008). Aphid dynamics in wheat as affected by weather and crop planting time. J. Agric. Res., 46: 361-366.

[32] Xiong, C.J. (1990). Study on the relationship between the occurrence of Rhopalosiphum padi (L) and the growing period of wheat. Insect Knowledge, 27: 5-7.

[33] Yang, X.W. (1990). Effects of temperature and light on the population growth of Schizaphis graminum (Rondani). Insect Knowledge, 27: 263-266.

[34] Zia, M.A., G.M. Aheer, M.K. Mumtaz and K.J. Ahmad. (1999). Field screening of sixteen advanced lines of wheat for resistance to aphids (Homoptera: Aphidae). Pak. Entomol., 21: 95-97.

Citation: H. A. Sahito et al., "Field Evaluation of Different Insecticides against Aphids (Homoptera: Aphidae) on Different Wheat, Triticum aestivum Varieties at Khairpur, Sindh ", International Journal of Research Studies in Zoology, vol. 3, no. 3, p. 11-19, 2017. http://dx.doi.org/10.20431/2454-941X.0303002

Copyright: () 2017 Authors. This is an open-access article distributed under the terms of the Creative Commons Attribution License, which permits unrestricted use, distribution, and reproduction in any medium, provided the original author and source are credited. 